Gower, C. and Capel, S. (2004) Newly qualified physical education teachers' experiences of developing subject knowledge prior to, during and after a Postgraduate Certificate in Education course.

Physical Education and Sport Pedagogy, 9 (2), 165-183.

Newly qualified physical education teachers' experiences of developing subject knowledge prior to, during and after a Postgraduate Certificate in Education course

\author{
Cathy Gower ${ }^{1}$ and Susan Capel ${ }^{2}$ \\ ${ }^{1}$ Department of Education and \\ ${ }^{2}$ Department of Sport Sciences \\ Brunel University
}

London

England

Key words: initial teacher education, physical education, subject knowledge 


\title{
Newly qualified physical education teachers' experiences of developing subject knowledge prior to, during and after a Postgraduate Certificate in Education course
}

\begin{abstract}
Office for Standards in Education (OFSTED) inspections of secondary Postgraduate Certificate in Education (PGCE) physical education courses in England between 1996 and 1998 (OFSTED, 1999) were critical of student teachers' subject knowledge. The purpose of this study was to investigate the development of subject knowledge and influences on the development of that subject knowledge in a sample of three newly qualified teachers (NQTs) who had completed a PGCE physical education course in England. The research comprised semi-structured interviews and analysis of documentation. Among these three NQTs there were some similarities, but more differences in terms of the development of subject knowledge as well as different influences on the development of subject knowledge. These results suggest that teacher educators may need to be flexible in how they approach and support the development of student teachers' subject knowledge. Results also suggest that teacher educators should work more closely with colleagues teaching sports-related undergraduate degree courses to support the development of subject knowledge for those students who wish to progress to a PGCE physical education course.
\end{abstract}

\section{INTRODUCTION}

Student teachers learning to become secondary physical education teachers in England can choose to study for a degree and then take a one year Postgraduate Certificate in Education (PGCE) course to gain Qualified Teacher Status (QTS), or can take a three or four-year undergraduate course at the end of which they receive their degree and QTS. However, more student teachers follow the PGCE route into teaching and recent government initiatives are likely to increase the number of student teachers following this route.

Inspections of secondary PGCE physical education courses carried out by the Office for Standards in Education (OFSTED) between 1996 and 1998 were critical of several aspects of student teachers’ preparation as teachers. They stated that:

'Students' subject knowledge is good in only four out of the ten providers, but in more than half of the courses inspected, a substantial minority of the students have significant weaknesses. This profile is below all other subjects and is a cause for concern' (OFSTED, 1999, p. 43).

OFSTED also noted that student teachers were inadequately prepared for PGCE courses in physical education as a result of their own schooling and the content of their first degrees. Therefore, in England there is an educational climate in which government initiatives support the PGCE route to gaining QTS in preference to the undergraduate route, whilst OFSTED are critical of PGCE physical education courses 
because of gaps in developing subject knowledge. But, what is meant by subject knowledge? Subject knowledge has been described in a number of different ways, two of which are discussed below.

The Department for Education and Employment (DfEE, 1998) identified four Standards which student teachers in England are required to develop and against which they are assessed at the end of their initial teacher education (ITE) course in order to gain QTS. The four Standards at the time of this study were: Subject Knowledge and Understanding; Planning, Teaching and Class Management; Monitoring, Assessment, Recording, Reporting and Accountability; and Other Professional Requirements. Together these comprise the knowledge identified as being needed to teach in England. These Standards use the term subject knowledge in a specific way, i.e. as Subject Knowledge and Understanding (SKU). This is how OFSTED (1999) used the term subject knowledge in their report.

Others use the term subject knowledge more broadly. This is equivalent to the descriptions for all four Standards in England. Shulman (1987) identified seven knowledge bases that student teachers require as part of their professional training:

- Content knowledge (the principles of conceptual organisation and of enquiry in the subject and the substantive (the factual information) and syntactic (the variety of ways in which basic concepts and principles of the subject are organised, and the ways in which validity or invalidity, truth or falsehood, are established) structures of the subject matter;

- General pedagogical knowledge (the broad principles and strategies of classroom management and organisation applicable to teaching in general);

- Curriculum knowledge (the materials and programmes that are teachers' 'tools of the trade');

- Pedagogical content knowledge (the knowledge which enables teachers to frame their content knowledge in a context specific way, which helps them to communicate the subject matter to pupils effectively);

- Knowledge of learners and their characteristics (the empirical or social knowledge of learners in general — what pupils of a particular age range are like, how they behave in schools/classrooms, their interests and preoccupations, their social nature, how contextual factors such as weather or specific events can affect their work and behaviour and the nature of the pupil-teacher relationship) and cognitive knowledge of learners (knowledge of child development which informs practice and knowledge about what a particular group of learners can and cannot know, do or understand that comes from regular contact with a specific group of learners);

- Knowledge of educational contexts (teaching contexts, ranging from the workings of the group, classroom, school governance/financing, to the character of communities and cultures, including the type and size of school, the catchment area, the class size, the extent and quality of support for NQTs, the amount of feedback teachers receive on their performance, the quality of relationships in the 
school, and the expectations and attitudes of the headteacher, that have a significant impact on teaching performance);

- Knowledge of educational ends, purposes, values and philosophical and historical influences (the purposeful activity through short-term goals for a lesson or series of lessons and long-term goals of intrinsically valuable experience or eventual value to a society).

Although others have also identified knowledge bases for teaching, their categories generally build on the knowledge bases identified by Shulman (1987). For example, Grossman (1990) identified four components of pedagogical content knowledge: knowledge and beliefs about the purposes of teaching a subject at different grade levels; knowledge of pupils' understanding, conceptions and misconceptions of subject matter; knowledge of curriculum materials available for teaching a subject and knowledge of horizontal and vertical curricula for the subject; knowledge of instructional strategies and representations for teaching particular topics. Likewise, others use different terms to describe different knowledge bases. For example, what Shulman (1987) referred to as content knowledge has been called 'subject matter knowledge’ by others (e.g. Grossman et al., 1989; McDiarmid et al., 1989; Bennett \& Carre, 1993; Calderhead \& Shorrock, 1997). In this paper content knowledge is used, except for reference to studies which specifically refer to subject matter knowledge.

Different ways of identifying knowledge needed for teaching are overlapping, but do not fit perfectly. In order to look at how the Standard for SKU (DfEE, 1998) relates to the knowledge bases of Shulman (1987), Ryan (2000) mapped the content identified in the Standard (DfEE, 1998) and aspects of the Standard identified by OFSTED (1999) in the inspection reports of 17 PGCE physical education ITE providers on which the OFSTED (1999) report was based. Table 1 shows that statements were identified in relation to SKU that fitted into four knowledge bases: content knowledge; curriculum knowledge; knowledge of learners and their characteristics; and pedagogical content knowledge.

Table 1: A comparison of the SKU Standard (DfEE, 1998) for the award of QTS with Shulman's (1987) knowledge bases

\begin{tabular}{|c|c|c|}
\hline $\begin{array}{l}\text { Shulman's } \\
(1987) \\
\text { knowledge } \\
\text { bases }\end{array}$ & $\begin{array}{l}\text { SKU Standard for the Award of QTS } \\
\text { (related to the specialist subject) }\end{array}$ & $\begin{array}{l}\text { Specific SKU as identified by OFSTED in } \\
\text { reports of inspections of secondary ITE } \\
\text { physical education courses }\end{array}$ \\
\hline $\begin{array}{l}\text { Content } \\
\text { knowledge }\end{array}$ & $\begin{array}{l}\text { - have a secure knowledge and understanding of the } \\
\text { concepts and skills to be able to teach confidently and } \\
\text { accurately at KS3 and KS4 and, where relevant, post- } \\
\text { 16; } \\
\text { - understand progression from the KS2 programmes of } \\
\text { study; } \\
\text { - know and can teach the key skills required for current } \\
\text { subject specific qualifications, for pupils aged 14-19, } \\
\text { and understand the contribution that the specialist }\end{array}$ & $\begin{array}{l}\text { - Identification of appropriate learning } \\
\text { objectives } \\
\text { - General principles inherent in the six } \\
\text { NCPE areas of activity in the NCPE } \\
\text { - Health and safety aspects of the subject } \\
\text { area } \\
\text { - The processes of planning, performing } \\
\text { and evaluating as part of PE SKU }\end{array}$ \\
\hline
\end{tabular}




\begin{tabular}{|c|c|c|}
\hline & subject makes to the development of the key skills; & \\
\hline $\begin{array}{l}\text { Curriculum } \\
\text { knowledge }\end{array}$ & $\begin{array}{l}\text { - have a detailed knowledge and understanding of the } \\
\text { National Curriculum (NC) programmes of study, end of } \\
\text { key stage descriptions for KS3 and, where applicable, } \\
\text { NC programmes of study for KS4; } \\
\text { - be familiar with the relevant KS4 and post-16 } \\
\text { examination syllabuses and courses, including } \\
\text { vocational courses; } \\
\text { - understand the framework of } 14-19 \text { qualifications and } \\
\text { the routes of progression through it }\end{array}$ & $\begin{array}{l}\text { - The NCPE areas of activity, programmes } \\
\text { of study and end of key stage descriptions } \\
\text { - Knowledge of what constitutes a broad } \\
\text { and balanced curriculum } \\
\text { - Post } 14 \text { and } 16 \text { examination courses in PE }\end{array}$ \\
\hline $\begin{array}{l}\text { Knowledge of } \\
\text { learners and } \\
\text { their } \\
\text { characteristics }\end{array}$ & $\begin{array}{l}\text { - understand how pupils' learning in the subject is } \\
\text { affected by their physical, intellectual, emotional and } \\
\text { social development; }\end{array}$ & $\begin{array}{l}\text { - Pupils' physical, cognitive, spiritual, } \\
\text { moral, social and emotional development } \\
\text { - Differentiation for pupils with special } \\
\text { educational needs }\end{array}$ \\
\hline $\begin{array}{l}\text { Pedagogical } \\
\text { content } \\
\text { knowledge }\end{array}$ & $\begin{array}{l}\text { - are aware of and know how to access recent inspection } \\
\text { evidence and classroom-relevant research evidence on } \\
\text { teaching secondary pupils in the subject, and know how } \\
\text { to use this to inform and improve teaching; } \\
\text { - know pupils' most common misconceptions and } \\
\text { mistakes; } \\
\text { - cope securely with subject-related questions which } \\
\text { pupils raise; } \\
\text { - have a secure knowledge and understanding of the } \\
\text { content specified in the ITE NC for ICT in subject } \\
\text { teaching; } \\
\text { - are familiar with subject specific health and safety } \\
\text { requirements and plan lessons to avoid potential } \\
\text { hazards. }\end{array}$ & $\begin{array}{l}\text { - Ability to access research and inspection } \\
\text { information } \\
\text { - Identification of pupils errors and } \\
\text { misconceptions } \\
\text { - Response to pupils questions } \\
\text { - The uses of ICT in PE }\end{array}$ \\
\hline
\end{tabular}

There is little research on the development of subject knowledge in student physical education teachers in England which identifies knowledge more broadly than one aspect of the Standard for SKU, i.e. the six areas of activity (athletics; dance; games; gymnastics; outdoor and adventurous activities; swimming and water safety) in the National Curriculum for Physical Education (NCPE). For example, Capel and Katene (2000) administered a questionnaire to student physical education teachers twice during their PGCE year to record their perceived level of knowledge/ confidence to teach each of the six areas of activity in the NCPE. Results showed that the majority of student teachers' had most knowledge/felt most confident in teaching the games area of activity and lacked knowledge/confidence in areas such as dance and outdoor and adventurous activities (OAA). They also found a complicated picture of changes in student teachers' perceptions of development of knowledge/ confidence during the PGCE year. There was a perceived increase in knowledge/ confidence in some activities over the PGCE year, most significantly in Dance, Gymnastics, OAA and Volleyball. However, there were a number of games activities in which student teachers did not perceive that their knowledge/confidence had increased over the year, e.g. football for male and netball for female student teachers. These activities were those in which the highest percentage of student teachers perceived good knowledge/ high confidence, both at the start and end of the year.

The results of this study are not surprising as the school physical education, extracurricular and out-ofschool activity experiences of these student teachers were dominated by games. Indeed, Capel and Katene 
(2000) attributed knowledge/confidence in teaching games and lack of knowledge/confidence in teaching other areas of activity as being due to student teachers' prior experiences, qualifications and knowledge of activities on entry to the PGCE course. Further, Hardy (1996) was not surprised that student teachers in his study felt vulnerable when planning for the range of NCPE activities, due to the time spent on practical activities on their undergraduate degree courses (and also in the PGCE year). Further, OFSTED (1999, p. 42) stated: 'Trainees are selected who are suitable for teaching, and many are enthusiastic and committed games players. However, most applicants have first degrees whose content is not related closely to the physical Education National Curriculum'.

Concern about lack of knowledge in specific areas of activity or activities is important not only because it influences confidence, but also because research has shown that pupils learning can be limited if they are taught by teachers with limited knowledge of the content being taught. For Siedentop (2002), the importance of physical education teachers having a reasonable mastery of the activities they teach, i.e. their content knowledge, was based on the premise that if 'they have little command of the content they will need to teach, [they have] no ability to take students beyond that introductory unit that seemingly gets taught again and again' (p. 372). Likewise, Graber (1995) stated that 'When student teachers have limited subject matter knowledge and are unfamiliar with the details of particular activities, they will be unable to make informed choices about how to teach that subject matter' (p. 164). Schempp et al. (1998) found differences in teachers' teaching activities in which they had expertise and teaching activities in which they had little or no expertise-irrespective of the amount of experience they had as teachers. They suggested that expertise in subject matter knowledge helps teachers: (a) better recognise problems in pupils’ learning; (b) plan more easily and in greater detail; (c) develop instructional strategies; and (d) have an increased level of comfort and enthusiasm.

Other researchers (e.g. Siedentop \& Eldar, 1989; Housner, 1993; Dodds, 1994) have suggested poor integration between content knowledge and pedagogical content knowledge. Graber (1995) found that student teachers knew they needed to combine content knowledge with pedagogical strategies but did not understand how to do so. How student physical education teachers taught an activity was shaped by how they had learned it themselves and also a single powerful individual could shape the beliefs of a student teacher about content knowledge as much as an entire programme of courses or experiences. Student teachers' experiences prior to an ITE course were therefore identified as central to the process of developing content knowledge.

Thus, it is important that research on subject knowledge in physical education recognises the importance of knowledge to teach the areas of activity, but also takes a broader view of what subject knowledge comprises. When looking at subject knowledge more widely in physical education, Rossi and Cassidy 
(1999) emphasised that, in order to reach a level of conceptual awareness to evaluate critically the conventions and routines that they have absorbed during their own education and while on school placement as part of their professional preparation, student teachers need to understand, for example, the unique experiences each area of activity in the NCPE can offer a pupil. They also need to have considered what the overall aims of physical education are and how the subject can contribute to a pupil's personal, social, moral, spiritual and cultural development.

The purpose of this study was to investigate the development of subject knowledge of three NQTs of physical education in England who had undertaken a PGCE route into teaching — prior to and during their PGCE course and after gaining QTS. A second purpose was to investigate influences on the development of subject knowledge. In the rest of this paper, except where these NQTs use a specific term and irrespective of whether it is used precisely or not, the term subject knowledge is used to identify the broad range of knowledge that student teachers need to develop to become effective teachers and the term SKU is used to identify the Standard (DfEE, 1998) (which includes different knowledge bases identified by Shulman (1987) in Table 1). Specific knowledge bases as identified by Shulman (1987) are referred to where appropriate (e.g. the term content knowledge is used when reference is made to knowledge about the areas of activity in the NCPE).

\section{METHODS}

\section{Subjects}

Three NQTs were identified as the sample for this research, one male and two females. These NQTs had all followed a BSc in Sport Sciences and gained QTS through the PGCE route in the same University in England in the academic year 1998/99 and were in the first year of a full time physical education teaching post at the time of the study. These three NQTs had been assessed against the Standards for the award of QTS (DfEE, 1998) as student teachers during their PGCE course. The sample was selected on the basis of several factors - including a balance of gender and access to a complete set of documentary data. However, the other factor that was taken into account was that these NQTs were all observed teaching by OFSTED during the inspection of the PGCE course at the University in 1998/99. The degree they followed was broadly based and after an initial foundation year students could focus their studies in a range of disciplines in the sport sciences. It did not include any specific focus on preparing students to enter a PGCE course.

\section{The course}

The PGCE course completed by these three NQTs was thirty-six weeks in duration, focusing on the teaching of physical education in secondary schools (11-18 year age range). The year was broken down into three terms, each of which combined university and school-based work. There were three phases of 
university-based work, each of three days per week: six weeks in the autumn term; six weeks in the spring term; and four weeks in the summer term. These comprised a combination of education and physical education theory and practical work, the latter comprising classroom-based physical education subject study; practical physical education addressing the six areas of activity in the NCPE; and general SKU enhancement activities and national governing body of sport awards. Practical for five areas of activity was common to all student teachers. In the games area of activity student teachers selected games identified as weaknesses in pre PGCE course content knowledge audits. On the other two days of these same weeks in the autumn term student teachers visited their placement school and observed teachers teaching and undertook focused tasks. This was followed by block school experiences. Student teachers completed seven weeks in one school and a total of thirteen weeks across the spring and summer term in a second school. In the spring and summer terms, outside block school experience, the two days per week spent in school alongside university-based work focused on student teachers undertaking a series of activities designed to reflect on university-based work, teaching a range of areas of activity in the NCPE and preparing for the NQT year. Therefore, in terms of percentages, $26.6 \%$ of the year was spent in university-based work and $73.3 \%$ in school-based work. This exceeded the government requirement of $60 \%$ school-based work (DfE, 1992) for PGCE courses. All aspects of the course were organised in partnership with an identified group of schools. In order to pass the course and gain QTS to enable them to teach in state schools, student teachers had successfully to meet the requirements in the four Standards for the award of QTS (DfEE, 1998).

\section{Instruments}

Data were collected from two sources: semi-structured interviews and documentary evidence. Consent was given for the interviews and to use the documents.

\section{Interviews}

Interviews were conducted over a week-long period in January 2000 by the principal author when the NQTs had been in their full time teaching post for approximately five months. The interviews were semistructured, utilising open-ended questions, within a framework which explored pre-course, on-course and post-course experiences. The term subject knowledge was not defined at this stage; rather it was used broadly. Towards the end of the interviews the NQTs were presented with a model of subject knowledge that combined the Standard for SKU (DfEE, 1998) with Shulman's (1987) definition of subject knowledge (as shown in Table 1), with a definition of what each aspect of the model represented. They were asked to identify the main influences on their development in each of the aspects identified. The structure of the interviews also allowed for issues emanating from a documentary analysis to be followed up. The interviews were recorded on audio-tape and then transcribed word-for-word. 


\section{Documents}

A range of sources of documentary evidence represented a secondary source of data collection. The documentary evidence which provided background information on these NQTs experiences of developing subject knowledge as they progressed from selection and admission to a PGCE course, through the course, to gaining QTS was:

- application form submitted to the Graduate Teacher Training Registry (GTTR) for a place on a secondary PGCE physical education course

- initial pre-course content knowledge audit of the six areas of activity in the NCPE - an assessment of own strengths and areas for development completed by every student teacher accepted onto the PGCE course, using a scale of: excellent; very good; satisfactory/adequate; poor/weak knowledge

- a self-evaluation of their learning completed by student teachers at the end of each term of the PGCE course (three in total). These required student teachers to reflect on the development of subject knowledge as they progressed through the course

- a profile document completed by subject mentors in negotiation with the student teacher, other teachers and University subject tutors which assessed student teachers formatively and summatively against the Standard for QTS at specified audit points in the PGCE year

- Career Entry Profile (CEP) which student teachers completed at the end of the ITE course and took with them to their first teaching post, indicating areas of strength and areas in need of further development in the four Standards areas.

These documents offered the perspectives of more than one party in that the student teachers (all sources), their undergraduate university tutors (references on the GTTR forms), and their subject mentors, other teachers and University tutors (the profiles) contributed to the writing of these documents.

\section{RESULTS AND DISCUSSION}

Using case studies of three NQTs was intended to provide a snapshot of their individual experiences of developing subject knowledge. It is important to acknowledge that a sample of three is not representative of all NQTs, or of a national picture of the experience of NQTs in developing subject knowledge. However, it allows possible issues to be identified which require further exploration and discussion. Results below include extracts from interviews and documentation. Names of NQTs have been changed.

\section{The development of subject knowledge}

\section{Pre-course experiences}

All three NQTs reported that the development of their subject knowledge started with an early love of sport. They were involved in both recreational and competitive physical activity from an early age, including extra-curricular activities at school and activities outside school. These experiences were 
predominantly games, particularly invasion games, such as football, netball and hockey, but also included other activities. Mary had considerable experience of both performing and coaching gymnastics, Susan had been involved in swimming and Mike had quite extensive experience of outdoor and adventurous activities (OAA).

All three NQTs had worked with young children and/or adolescents prior to applying for their PGCE place, Mary and Susan in a coaching or teaching capacity and Mike in a youth work role. They all viewed this as significant in the development of their subject knowledge for a career in physical education teaching.

There was no common physical education examination experience between the ages of 14 and 18 amongst these NQTs. Neither Mary nor Susan had followed a sports-related General Certificate of Education (GCSE) from age 14-16 years or Advanced (A) level from age 16-18 years. Although Susan was sure at an early age that she wanted to be a physical education teacher, she did not see these qualifications as necessary for preparing her for this career. Mary was less sure about her future career and selected her courses at the age of 14 on the basis of ability to succeed. Only Mike had followed any physical education related examinations from the age of 14 (GCSE Physical Education and Business and Technician Education Council (BTEC) National Diploma in Leisure Studies). He considered this to have been significant in helping him to develop his subject knowledge.

By chance the main core teachers of the BTEC were ex-physical education teachers from secondary schools. That was a major influence and a major help. We also had an extra unit of physical recreation which was not part of our normal timetable and during this time we spent an hour and a half to two hours everyday working with young people (Mike)

There is no existing research as to the significance of sport or physical education related educational qualifications between 14 and 18 years in providing a subject knowledge foundation for prospective physical education teachers. However, research conducted by Capel and Katene (2000) attached significance to students' undergraduate degree courses and its impact on subject knowledge development. Generally, the early practical experiences of physical education and sport of the three NQTs in this study were not extended significantly in their undergraduate degree course. Their choices on and focus of their undergraduate degrees revealed a range of different experiences. GTTR forms showed that both Mary and Susan focused their undergraduate choices on social sciences and had limited background in physical sciences, whereas Mike chose a combination of social and physical sciences modules. However, common to all three was limited practical work in their undergraduate profile. Susan undertook some modules 
which incorporated practical sport but Mary and Mike did not select any modules which included practical sport during their undergraduate degree studies.

It was only Mike who made conscious choices on the basis of their potential use in his chosen career, despite Susan being the only one of the three who was sure that her career was going to be as a physical education teacher. For both Mary and Susan, their choices were determined by the potential grade they might achieve to count towards their overall degree classification as opposed to the potential value of the module in developing subject knowledge for a career in physical education teaching. However, would the students have chosen an alternative package if they had realised its significance in preparing them for a PGCE course and a potential career as a physical education teacher? Interviews revealed mixed opinions on their choice of options.

I wanted a good degree and that's why I did it. On reflection I wouldn't have done, possibly not anyway (Mary)

Being a physical education teacher...was always in the scheme of things. But my module choices were not affected by this potential choice of career. My choices did underpin some of the knowledge I have now. That obviously progressed through the modules that I took...Did hockey and tennis as undergraduate module activities because I knew more about them (Susan)

I felt...if I was going to seek a physical education teaching profession, I would need a balanced content...... I needed to map out what I chose to ensure that when I did apply for a PGCE I had more chance of getting on because of my undergraduate modules (Mike)

The interviews also showed that these three NQTs did not necessarily make a connection between their undergraduate studies and their potential value for their subsequent ITE course. Mike stated that he was aware of the need for balanced content in his choices. He viewed the fact that he managed to study a range of sport science disciplines as positive, however, he would have increased the amount of practical work undertaken. He stated that:

In year one I did some [practical] as part of a statistical analysis unit. It was like an observation and analysis lesson. You'd go out and perform a particular task and then go back to a lab and log the data. It was football, rugby, a bit of tennis. It was games orientated because of the lecturers we had. Because of these limitations we stuck to games. I wouldn't change things in any way, I felt it adequately prepared me. One thing I would change was the choice of biomechanics as it has gone out of the A level content, and changed it for a practical module (Mike) 
This highlights a key issue in terms of the relationship between sports-related undergraduate degrees which are not designed to prepare students for entering a PGCE course and the needs of students wishing to progress to a PGCE physical education course, particularly in light of government recommendations that a PGCE student teacher's previous education should provide a foundation in the subject area which they then go on to teach (DfEE, 1998). The degree course followed by these three NQTs did not claim to prepare students to enter an ITE course. Therefore, it is not structured to encourage students who may wish to progress to a PGCE physical education course to consider breadth and balance of experience and choose modules that allow them to broaden their subject knowledge or address gaps in subject knowledge suitable for teaching physical education. On the other hand, on sports-related degree courses students may be encouraged to make choices that enable them to develop specialisms, building on existing strengths. One illustration of this was Susan selecting her strengths of hockey and tennis, rather than targeting activities in which she needed to enhance content knowledge prior to applying for a PGCE course. This may also apply to the theoretical underpinning which will inform students teaching of an activity and enable them to teach examination courses to pupils above the age of 14. If students on undergraduate sports-related degree courses are to be prepared adequately for a PGCE course, it may be necessary to reconsider what is offered and/or strengthen support, advice and guidance on choices in relation to possible careers prior to the start of the course. This may require closer liaison with colleagues working on sports-related degree courses as to what students need for a PGCE course.

However, out of these three NQTs, only one was sure that she would pursue a career as a physical education teacher after graduation. It is important therefore, that students receive guidance early on in their undergraduate studies on how to select a package which allows them the flexibility to change their mind about a possible future career and yet also prepares them adequately if they decide that a career as a physical education teacher is their preferred route.

Lack of adequate preparation on their undergraduate degree course seemed to be compounded by students' in relation to their identified gaps in content knowledge. Once these NQTs had been accepted onto the PGCE physical education course and strengths and gaps in content knowledge had been identified in their initial pre-course content knowledge audit and at interview, only Mike addressed areas in which he lacked knowledge/confidence.

I felt it necessary to go away and look at areas such as class management. I did look at a few sports, rugby as one, looking up rules of sports that I would cover. I did go away and look at some of the gymnastics material (Mike) 
This would suggest that following identification of gaps in content knowledge in an initial pre-course content knowledge audit and at interview strategies and support systems to help successful applicants address weaker areas before they begin the PGCE course itself could be strengthened. This supports Hardy (1997) who suggested that, in future, selection procedures for PGCE physical education courses should pay more attention to prospective teachers' knowledge and experience of activities in the NCPE. Decisions should be made at interview about the knowledge that applicants are bringing to the course and the minimum amount of knowledge that they should acquire before the course starts. This may require some applicants to develop knowledge in and about some activities as a condition of entry to the PGCE course. Some summer courses have now been set up to address these, but students could also be directed to coaching courses/qualifications, volunteer work, Sports Leaders awards or the Duke of Edinburgh Award scheme which are relevant to teaching physical education. However, checks could be strengthened in relation to students who need them.

In summary, NQTs initial experiences and therefore development of physical education related subject knowledge was varied and there was no identifiable pathway which they had all followed in preparation for their future career. All three NQTs were involved in sport from an early age and had a strong games background. Their own personal involvement in sport led them into assistant teacher, coach or youth work roles with younger pupils or club members, providing experience of working with children prior to entering the PGCE course. They had a varied undergraduate profile with limited practical content in their degree course. Although findings from this small sample support OFSTED (1999) criticisms, this particular sample of NQTs also had strengths beyond games, including gymnastics, swimming and OAA.

\section{PGCE on-course experiences}

Research has shown that without sufficient knowledge/confidence in their own content knowledge, student teachers teaching practice will be limited. As HMI (1987) stated, insecurities in content knowledge lead to restricted practices. These three NQTs entered the PGCE course with different content knowledge profiles according to the initial pre-course audit. The only area of activity in the NCPE in which all three lacked knowledge/confidence was dance. Susan and Mike both lacked knowledge/confidence in gymnastics, but this was an area in which Mary had good knowledge and was very confident. Other than that, there was a range of experience and knowledge/confidence in the other four areas of activity.

Self evaluations at the end of each term showed that, in general, all three of these NQTs were positive about the contribution both university and school-based work made to the development of their subject knowledge, but they valued university and school-based experience differently. However, all three placed high value on university-based work in the areas in which they considered themselves to be weaker. 
Although university and school-based experience offered different opportunities at different times, there was not one experience that proved to be more influential in the development of subject knowledge than any other. In relation to university-based experiences, much of the comment of the three NQTs was based around the areas of activity in the NCPE:

.....We did a content knowledge audit to say what our strengths and weaknesses were and...then decided what activities we had courses in. Everybody did gym and dance which obviously was of great use to me as those are my two weakest areas...Basically it ended up that you either did rugby or football. Rugby, I loved it - brilliant, but the fact was I felt like I could have done with football as well (Susan)

Athletics, I think we had four or five sessions that were very good...we had either hockey, netball or basketball. The ideas were quite good. For things like hockey, it did give me a little bit of a start but it wasn't enough if you didn't have much knowledge to start with (Mary)

It opened my eyes to the amount of work and to the need to go away for certain areas such as gymnastics and dance, some of the areas I hadn't had experience of prior to this. I needed to go away and find out what was required, what could be done and I did aim to try and do that quite early on in the course. That was kind of a prompt from lecturers as well as myself realising through lecture material that this was an area which I might have a bit of difficulty in terms of subject knowledge because it was limited at the beginning of the course (Mike)

University-based work for weaker areas of activity such as gymnastics and dance was seen as essential by all three NQTs. They also acknowledged that university-based work alone was insufficient to address existing gaps in subject knowledge. Mike referred to the need to go away and do some additional professional development in areas in which he realised he was weaker. For him, pre-course lack of concern about subject knowledge gaps changed to a realisation that limitations needed to be addressed.

It was like, right here are the basics - right now I'm going to move it on really, really quickly and I was struggling to do the basics. I was having to do more advanced things when I couldn't do the easy things. Now I know how kids feel when you tell them do something and they're like 'I can't do that, so how can I do that' (Mary)

Susan acknowledged that there was a link between certain types of games classification, e.g. invasion games, and that this had informed her knowledge. However, she did not believe that examining these 
links supported her perceived needs for developing knowledge sufficiently - she still wanted some support in individual games such as football. Both Mary and Susan commented on the structure of the course. Mary suggested that the theory and practical needed to be more closely linked for the whole picture to begin to make sense.

All three NQTs commented on the time gap between university and school-based work and/or lack of opportunity to teach activities in school for a sustained period of time.

In January and February we did athletics but I didn't teach it until the following May but the knowledge was there, it was just at a bit of a distance (Susan)

The dance was very helpful when we did it at the beginning but then I didn't teach it for all that Christmas term and then had to come back at the beginning of February (to teach it) (Mary)

(Dance) was still a concern at the end of the course because on my first teaching block I didn't teach dance and on my second block I only taught three lessons of dance, which, although successful, wasn't enough (Mike)

Long gaps between university and school-based work in a specific activity were viewed by these NQTs as a barrier to the development of content knowledge, in particular the relationship between content knowledge and the teaching of the activity. The knowledge they had acquired about athletics and dance in university-based work needed to be contextualised in order for it to have real value and the time gap that occurred prevented this from happening. This suggests that it may be beneficial for teacher educators to consider how student teachers' university and school-based experiences can be paralleled more closely. However, this is not easy due to different teaching arrangements in different schools in a partnership.

Further examination of the relationship between university and school-based work showed that:

I think the university has quite a strong influence because you can go through things like curriculum content. Whereas school, all they are really concerned with is the fact that you teach what they want you to teach in that six week block (Mary)

Obviously one main difference is the fact that within university-based lectures it is more theory orientated and you're discussing it in principle. You don't have a group of year elevens [on which] to practice what you are trying to get across. However, when you're at school you might, for example, take a lesson like GCSE physical education. You might be looking at the cardiovascular system and it 
might all be just off the board. At the end of the lesson, the feedback that you might receive from an experienced teacher would lead you then to looking at different ways that you can get across the subject knowledge...It just brings in all the different concepts such as the different teaching styles and the materials that you can use to enhance the subject knowledge (Mike)

There were different perceptions of the school influence on the development of knowledge. Mary perceived school-based work as restrictive to the point that it dictated exactly what she had to teach and how, without a sufficient degree of flexibility to allow her to make some meaning of it for herself. She also suggested that she had been subjected to unrealistic expectations in relation to the development of knowledge and this pressurised experience helped her to empathise with pupils who struggle in the school context.

The whole scheme of work was written out completely by my mentor who also happened to be observing my dance lessons. She had very strong ideas about how she wanted things done, how she would do things. If they weren't done the same way that she would do them it felt like that was why the criticism was there. I know they weren't brilliant lessons, but I'd come out feeling quite demoralised. If there was a way I could not teach the lesson the next week I would. When I was looking through the paper for jobs, I was looking specifically for schools that didn't teach dance (Mary)

This excerpt is a powerful illustration of the potentially negative effect that school experience can have upon a student teacher. The mentor in this situation had a strong philosophy on dance content and how it should be taught to pupils. She sought to influence the way in which Mary acquired this knowledge by requiring her to replicate her own beliefs rather than analyse and synthesise for herself. This approach did not allow Mary to make sense of content knowledge and its application within the teaching context for herself and imposed a restrictive framework in which she was unable to develop any depth of understanding in dance. Such an approach may restrict the development of student teachers' knowledge to the point where they avoid having to teach certain areas of activity.

On the other hand, Mike viewed school-based work as essential in making the transition from content knowledge to pedagogical content knowledge. Feedback from school staff supported him in developing a range of strategies to present the content knowledge to pupils. This experimentation with strategy was consistent with the recommendations of Wilson, Shulman and Richert (1987) who supported the need for teachers to develop a repertoire of pedagogical content knowledge in order to enhance learning. 
Their profile documents indicated that these NQTs were provided with opportunities in school to address areas in need of development. All three NQTs reported a sense of a developing profile of experience as they progressed through the year. However, this did not guarantee that they completed the year feeling confident in these areas. For example, Mary targeted dance for content knowledge development on school experience and yet identified it as one of her weaker areas in her Career Entry Profile (CEP) at the end of the year. For two of the NQTs, knowledge of dance and gymnastics and knowledge for teaching examination courses to pupils between 14 and 18 years continued to be a cause for concern throughout the year and into their CEP. This was consistent with OFSTED findings that although the ITE process on the whole was good, the end product may not be as it should be (OFSTED, 1999).

\section{Post-qualification experiences}

When the NQTs were asked to reflect on knowledge which continued to represent a target for them after approximately five months of teaching, all three stated the need for continued support in examination work to pupils between 14 and 18 years - particularly theory work.

\section{I hadn't done a great deal of classroom teaching. I'd taken about eight lessons of GCSE physical education, probably less than that actually and was not particularly confident in the classroom, just because it's a completely different situation to one when you're in a gym or on the field (Mary)}

The one thing that I did find...was that it was assumed that, right PGCE course - teaching physical education. And the fact was that we didn't really deal generally with teaching in the classroom, which was quite different from teaching outside or in the gymnasium, sportshall, whatever (Susan)

The two that I wanted to address was to gain a greater knowledge in dance and particularly to teach A level physical education and I'm now teaching the observation and analysis which of all the units was possibly the one in which my knowledge was better just because of the experience I've had at university (Mike)

The expansion of examinations for pupils between 14 and 18 years in physical education/ sport requires physical education teachers to be confident teaching in the classroom as well as in the more traditional working areas of the gymnasium and playing field. The content of these NQTs first degrees should prepare them for teaching some of the theoretical aspects of examinations (biomechanics, physiology, psychology, sociology), depending on their choice of modules on their undergraduate course. However, this finding suggests that both university and school-based work during the PGCE course did not provide sufficient experience to enable student teachers to feel confident in teaching classroom-based theoretical aspects of physical education. It cannot be taken for granted by teacher educators that because student 
teachers have covered the theoretical content in their first degree course, they are able to teach it or that they will be able to translate this content knowledge to make it accessible for pupils in a classroom-based context. Indeed, Reeves (1993) stated that 'Even when students have appropriate subject knowledge there remains the problem of practical application' (p.54). It is important, therefore, that both universities and schools support student teachers adequately by providing them with a range of opportunities to understand and experience classroom-based teaching strategies and to be able to reflect on how effective they are in facilitating pupils learning.

All three NQTs stated that they had used their CEPs and identified areas for improvement to negotiate inservice provision since starting their first teaching post. This provision had taken different forms for each of them and included team teaching, observation, negotiation of timetables to accommodate weaker areas; and attendance at externally run courses.

\section{Influences on the development of SKU}

Results from interviews showed that for these three NQTs, their ITE course was only one of the many influences on the development of subject knowledge. There were many other influences:

I loved school...and just loved physical education. I had really, really good physical education staff there...I used to go along to practice and help out with the younger kids when I was in the sixth form, helping to coach and manage the teams. I'm still in touch with my old physical education teachers (Susan)

There was a particular teacher who ran the football side, when I was third and fourth year juniors. He would take the football team every Saturday, that was a major influence in getting involved in sport within school..... When I was sixteen I started to work with Dave, helping out with sailing and canoeing, some map reading exercises. Then when I was eighteen I joined the project, that led to me taking wall climbing sessions. It led to me going on some Duke of Edinburgh work. This was a very big help to me and I acquired a lot of knowledge. The youth work side of things was a major influence on me becoming a physical education teacher (Mike)

These findings reinforce Graber’s (1995) research which emphasised the significance of a student teacher's own learning experiences at school and the influence of powerful individuals. Further, she identified that potentially these can have more impact than an entire ITE course or school experiences.

The model in Table 1 combining the Standard area of SKU (DfEE, 1998) and Shulman's (1987) definitions of knowledge bases was then presented to the NQTs with a definition of what each aspect of 
the model represented. The NQTs were then asked to identify what had most influenced the development of their knowledge in each of these areas. Results are shown in Table 2.

Table 2: Key influences on the development of subject knowledge identified by the NQTs

\begin{tabular}{|l|l|l|l|l|}
\hline & $\begin{array}{l}\text { Content } \\
\text { Knowledge }\end{array}$ & $\begin{array}{l}\text { Curriculum } \\
\text { Knowledge }\end{array}$ & $\begin{array}{l}\text { Knowledge of learners and } \\
\text { their characteristics }\end{array}$ & $\begin{array}{l}\text { Pedagogical content } \\
\text { knowledge }\end{array}$ \\
\hline Mary & $\begin{array}{l}\text { School-based } \\
\text { experience. Personal } \\
\text { participation } \\
\text { experiences. Family }\end{array}$ & $\begin{array}{l}\text { University postgraduate } \\
\text { experience. Family }\end{array}$ & $\begin{array}{l}\text { PE teachers at school. } \\
\text { Personal coaching } \\
\text { experiences }\end{array}$ & $\begin{array}{l}\text { University postgraduate } \\
\text { experience }\end{array}$ \\
\hline Susan & $\begin{array}{l}\text { School-based } \\
\text { experience }\end{array}$ & $\begin{array}{l}\text { University postgraduate } \\
\text { experience }\end{array}$ & School-based experience & $\begin{array}{l}\text { School-based experience. } \\
\text { Friends }\end{array}$ \\
\hline Mike & $\begin{array}{l}\text { Undergraduate and } \\
\text { postgraduate } \\
\text { university experience }\end{array}$ & $\begin{array}{l}\text { University postgraduate } \\
\text { experience }\end{array}$ & $\begin{array}{l}\text { BTEC post-16 course. } \\
\text { University postgraduate } \\
\text { experience }\end{array}$ & $\begin{array}{l}\text { Undergraduate and } \\
\text { postgraduate experience. } \\
\text { School-based experience }\end{array}$ \\
\hline
\end{tabular}

These results indicate that there was no real pattern in terms of influence across different aspects of subject knowledge. For Mike, undergraduate and postgraduate university experiences were most influential, whereas Susan valued school-based work most in terms of the development of knowledge across this identified range of areas. Mary, on the other hand, cited a wider variety of influences on her SKU and viewed her PGCE course experiences as only part of the equation.

\section{CONCLUSION}

This study has provided some background information about the development of subject knowledge and influences on the development of that knowledge in a sample of three NQTs who had completed a secondary PGCE physical education course in England.

Results showed that these NQTs generally had a limited view of how they defined subject knowledge. Their descriptions focused on knowledge of/confidence to teach the six areas of activity of the NCPE and theoretical aspects of examinations to pupils between 14 and 18 years, i.e. content knowledge in the Standard SKU. Further research is needed to look at whether the use of the term subject knowledge is confusing in light of the use of the term SKU as one of the Standards for the award of QTS, whether these descriptions of subject knowledge were used to illustrate a point, or whether NQTs hold a limited view of knowledge they need to be an effective teacher. If the latter, the implications of this for the content and focus of PGCE courses need to be considered. Other research is needed to look at, for example, how student teachers, mentors and others define subject knowledge and how this influences the development of subject knowledge by student teachers and NQTs.

Results showed differences between the three NQTs in the development of subject knowledge prior to, during and after the PGCE course as well as different influences on the development of subject knowledge. These results suggest that teacher educators should take account of the needs of individual 
student teachers, be flexible in how they approach the development of student teachers' subject knowledge on a PGCE course, and support student teachers to develop their understanding of subject knowledge - both specific in relation to SKU and those knowledge bases identified by Shulman (1987) as being included in this Standard, but also in relation to other knowledge bases.

Results also suggest that further research is needed on whether the preparation of students through a sports-related degree then a PGCE is appropriate and how students who might progress to a PGCE physical education course receive the information, guidance and support they need early enough for them to select an undergraduate package which provides them with a suitable preparation for a career as a physical education teacher, whilst still retaining the flexibility to keep their career options open if they decide that teaching is not for them.

Research is needed also to consider the development of all four Standards identified by DfEE (1998) against which student teachers are assessed for the award of QTS in England and how student teachers and NQTs integrate these four standards in order to become effective teachers of physical education. However, such research needs to be undertaken in relation to the revised Standards for the award of QTS (TTA, 2001).

\section{REFERENCES}

Bennett, N. and Carre, C. (Eds) (1993). Learning to teach (London, Routledge).

Calderhead, J. and Shorrock, S. B. (1997). Understanding teacher education (London, Falmer Press).

Capel, S. and Katene, W. (2000). Secondary PGCE physical education students' perceptions of their subject knowledge. European Physical Education Review, 6 (1), 46-70.

Department for Education (DfE) (1992). Circular 9/92: Initial teacher training (secondary phase) (London, DfE).

Department for Education and Employment (DfEE) (1998). Teaching: High status, high standards (circular 4/98) (London, HMSO).

Dodds, P. (1994). Cognitive and behavioural components of expertise in teaching physical education. Quest, 46, 153-163.

Graber, K.C. (1995). The influence of teacher education programs on the beliefs of students: general pedagogical knowledge, pedagogical content knowledge and teachers education-course work. Journal of Teaching in Physical Education, 14 (2), 157-178.

Grossman, P.L. (1990). The making of a teacher: Teacher knowledge and teacher education (New York, Teachers College Press). 
Grossman, P.L., Wilson, S.M. and Shulman, L.E. (1989). Teachers of substance: subject matter knowledge for teaching, in: M.C. Reynolds (Ed) Knowledge Base for the Beginning Teacher (New York, Pergamon).

Hardy, C. (1996). Trainees’ concerns, experiences and needs: Implications for mentoring in physical education, in: M. Mawer (Ed) Mentoring in Physical Education: Issues and Insights (London, Falmer Press).

Hardy, C. (1997). Sources of conflict during the school experience of pre-service physical education teachers. European Physical Education Review, 3 (2), 116-128.

Her Majesty's Inspectorate (HMI) (1987). Quality in schools: the initial training of teachers (London, HMSO).

Housner, L. D. (1993). Teacher cognition, in: T. Martinek (Ed) Psycho-social Dynamics of Teaching Physical Education (Dubuque, IA, Brown/Benchmark).

McDiarmid, G.W., Ball, D.L. and Anderson, C.W. (1989). Why staying one chapter ahead doesn't really work: subject specific pedagogy, in: M.C. Reynolds (Ed) Knowledge Base for the Beginning Teacher (New York: Pergamon).

Office for Standards in Education (OFSTED) (1999). Secondary initial teacher training - secondary subject inspections 1996-98. Overview report (London, HMSO).

Reeves, S. (1993). National Curriculum Council in association with CATE and SEAC subject specific conferences on the National Curriculum and initial teacher training (secondary): Spring term 1993. Bulletin of Physical Education, 29 (2), 53-58.

Rossi, T. and Cassidy, T. (1999). Knowledgeable teachers in physical education: a view of teachers' knowledge, in: C.A. Hardy and M. Mawer (Eds) Learning and Teaching in Physical Education (London, Falmer Press).

Ryan, C. (2000). An investigation into individual postgraduate physical education students' experiences of developing subject knowledge prior to, during and after gaining Qualified Teacher Status. Unpublished MEd Dissertation, Brunel University.

Schempp, P., Manross, D., Tan, S.K.S. and Fincher, M.D. (1998). Subject expertise and teachers' knowledge. Journal of Teaching in Physical Education, 17, 342-356.

Shulman, L.S. (1986). Those who understand: knowledge growth in teaching, Educational Researcher, 15 (2), 4-14.

Shulman, L.S. (1987). Knowledge and teaching: foundations of the new reforms, Harvard Educational Review, 57, 1-22.

Siedentop, D. (2002). Content knowledge for physical education. Journal of Teaching in Physical Education, 21, 368-377.

Siedentop, D. and Eldar, E. (1989). Expertise, experience and effectiveness. Journal of Teaching in Physical Education, 13, 375-394. 
Teacher Training Agency (TTA) (2001). National standards for qualified teacher status (London, TTA). Wilson, S.M., Shulman, L.S., and Richert, A.E. (1987). 150 different ways of knowing: Representations of knowledge in teaching, in: J. Calderhead (Ed) Exploring Teachers’ Thinking (London, Cassell). 